\title{
Radioactivity Measurements and Radiation Dose Assessments in Ground Water of Al-Baha Region, Saudi Arabia
}

\author{
Amal Hussain Al-Ghamdi \\ Department of Physics, Faculty of Science, University of Jeddah, Jeddah, KSA \\ Email: ahg246@yahoo.com
}

How to cite this paper: Al-Ghamdi, A. H. (2019). Radioactivity Measurements and Radiation Dose Assessments in Ground Water of Al-Baha Region, Saudi Arabia. Journal of Geoscience and Environment Protection, 7, 112-119.

https://doi.org/10.4236/gep.2019.710009

Received: September 2, 2019

Accepted: October 25, 2019

Published: October 28, 2019

Copyright $\odot 2019$ by author(s) and Scientific Research Publishing Inc. This work is licensed under the Creative Commons Attribution International License (CC BY 4.0). http://creativecommons.org/licenses/by/4.0/

\begin{abstract}
Twenty samples of ground water were collected from different wells in Al-Baha region which is located at south-east of Saudi Arabia. Gamma spectrometer based on HPGe crystal was applied to determine activity concentrations in $\mathrm{Bq} \cdot \mathrm{L}^{-1}$ of the natural radio nuclides: Radium-226 and Thorium-232 series also Potassium-40. The measured results indicate that the average concentrations of ${ }^{226} \mathrm{Ra},{ }^{232} \mathrm{Th}$ and ${ }^{40} \mathrm{~K}$ in the studied samples were $0.85,0.43$, and $2.84 \mathrm{~Bq} \cdot \mathrm{L}^{-1}$, respectively. The average annual estimated effective dose was found to be $0.058 \mathrm{mSv} / \mathrm{y}$ which is lower than the annual limit of the dose allowed by WHO Thus, it has no harmful effects on health.
\end{abstract}

\section{Keywords}

Drilled Well Water, Natural Radioactivity, Doses, Hpge, Gamma Spectroscopy

\section{Introduction}

Natural radioactivity in groundwater arises from ${ }^{238} \mathrm{U},{ }^{232} \mathrm{Th},{ }^{40} \mathrm{~K}$ and their decay products which are produced as a result of the interactions between rocks and water (Todorović et al., 2012; Kraemer \& Genereux, 1998). Consequently these radionuclides transported in ground water can enter the food chain through irrigation waters and the water source through ground water wells (Malanca et al., 1998). Thus, the ingestion of radionuclides in drinking water causes human internal exposure (Degerlier \& Karahan, 2010). The estimated exposure of natural radioactivity sources contributes dose was $2.4 \mathrm{mSv} \mathrm{y}^{-1}$ (cosmic ray 0.4 , terrestrial gamma ray 0.5, radon 1.2, and food and drinking water 0.3) (UNSCEAR, 2000). So, determinations of natural radioactivity concentrations in bedrock wells were important to estimate the dose in the water samples (Salih et al., 2002). In the 
south-west of Saudi Arabia (Al-Baha region), there are no rivers, lakes, and springs. Therefore, people depend on the underground water especially those coming from wells. These wells must be safe and of good quality. Concentration levels of ${ }^{226} \mathrm{Ra},{ }^{232} \mathrm{Th}$ and ${ }^{40} \mathrm{~K}$ in ground water used in this region and the radiological impacts of the consumed drinking water have not been reported in literature previously. So, the aim of this work is to determine the concentration values of natural radionuclides present in the well water samples collected from different location in Al-Baha region and estimate the corresponding radiation doses for people consuming these waters. This work is necessary due to the demands of having the database available on the waters and is highly required to keep human drinking water standards. The obtained data in this study may afford baseline levels of natural radioactivity in such water and provide background information for future research on drinking water for radiological protection of the human.

\section{Materials and Method}

\subsection{Study Area}

In order to determine the natural radioactivity in ground water, twenty water samples were collected from most frequently used wells spread in different locations of Al-Baha region. It is located in the south-east of Saudi Arabia $\left(20^{\circ} 0^{\prime} 0^{\prime \prime} \mathrm{N}, 41^{\circ} 30^{\prime} 0^{\prime \prime} \mathrm{E}\right)$, as shown in Figure 1. The sampling locations were chosen mostly based on population density and accessibility. Al-Baha region is an agricultural area, the main agro products, are wheat, vegetables and fruits. This region was chosen based on the active usage of ground water for drinking and for irrigation purposes made by locals of the area which can also be a source of radionuclides in foods.

\subsection{Samples Collection, Preparation and Measuring}

The collected water samples were acidified with nitric acid to avoid the collection of organic materials, then each sample was filled into $500 \mathrm{ml}$ capacity polyethylene Marinelli beakers (IAEA, 1989). Before use the containers were washed

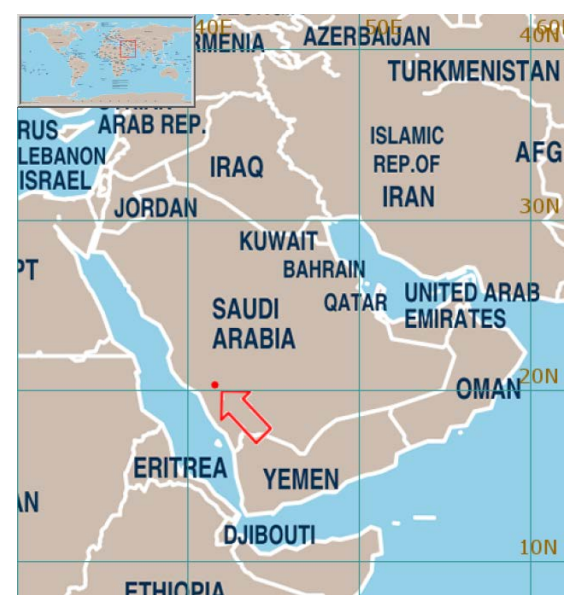

Figure 1. The study area (Al-Baha region-Saudi Arabia). 
with dilute $\mathrm{HCl}$ and rinsed with distilled water. The Marinelli beakers were sealed and stored for more than 4 weeks before counting to reach the secular equilibrium between ${ }^{226} \mathrm{Ra}$ nuclides and ${ }^{232} \mathrm{Th}$ nuclides and their daughters for gamma ray measurements (Abbady, 2004). Detection and measurements of the sample concentrations were carried out using a coaxial high-purity germanium (HPGe) detector with relative efficiency of 25\% and FWHM $2.0 \mathrm{keV}$ at 1332 $\mathrm{keV}$, of ${ }^{60} \mathrm{Co}$. The detector was housed inside a thick lead shield to reduce the background of the system. Genie 2000 basic spectroscopic software was installed in the computer for data acquisition and analysis. The system was calibrated for energy and efficiency on a regular basis in (IAEA, 1989). Each sample after equilibrium was kept on the top of the HPGe detector and counted for $36,000 \mathrm{~s}$. The background was measured every week under the same conditions of sample measurement.

\subsection{Calculations of the Activity Concentration}

The activity of ${ }^{226} \mathrm{Ra}$ was determined based on the gamma ray energies of 351.9 $\mathrm{keV}$ from ${ }^{214} \mathrm{~Pb}$ and $609.3,1120.3$ and $1764.5 \mathrm{keV}$ (from ${ }^{214} \mathrm{Bi}$ ). The activity concentration of ${ }^{232} \mathrm{Th}$ was determined based on gamma ray energies of $338.8,911.2$ and $968.97 \mathrm{keV}$ from ${ }^{228} \mathrm{Ac}$ and $583.0 \mathrm{keV}$ from ${ }^{208} \mathrm{Tl} .{ }^{40} \mathrm{~K}$ was determined directly by its emission energy of $1461.8 \mathrm{keV}$ gamma-ray line. The activity concentrations $A_{w}$ of the natural radionuclides in the measured samples were calculated using the equation (UNSCEAR, 2000):

$$
A_{w}\left(\mathrm{~Bq} \cdot \mathrm{L}^{-1}\right)=C a / \varepsilon P \gamma m
$$

where: $\mathrm{Ca}$ is the net gamma counting rate (counts per second), $\varepsilon$ the detector efficiency of the specific $\gamma$-ray, $P \gamma$ the absolute transition probability of Gamma-decay and $m$ the mass of the sample $(\mathrm{kg})$.

\section{Results and Discussion}

\subsection{Activity Concentrations of ${ }^{226} \mathrm{Ra},{ }^{232} \mathrm{Th}$ and ${ }^{40} \mathrm{~K}$}

The concentrations in Bq. $\mathrm{L}^{-1}$ of radionuclides ${ }^{226} \mathrm{Ra},{ }^{232} \mathrm{Th}$, and ${ }^{40} \mathrm{~K}$ measured in the water samples were listed in Table 1 . As shown, in this table, ${ }^{226} \mathrm{Ra}$ activities It ranged from $0.24 \mathrm{~Bq} \cdot \mathrm{L}^{-1}(w 17)$ to $1.54 \mathrm{~Bq} \cdot \mathrm{L}^{-1}(w 11)$. It was not detected in four samples $(w 3, w 9, w 18$ and $w 20)$ and the measured samples $(w 5, w 6, w 7, w 10$ and w13) were higher than the recommended limits of $1.0 \mathrm{~Bq} \cdot \mathrm{L}^{-1}(\mathrm{WHO}, 2006)$. ${ }^{232} \mathrm{Th}$ series were detected in eight samples only, the lowest value was $0.15 \mathrm{~Bq} \cdot \mathrm{L}^{-1}$ (sample 15) and the highest value was $0.81 \mathrm{~Bq} \cdot \mathrm{L}^{-1}(w 16)$. The results show that the concentration values of ${ }^{226} \mathrm{Ra}$ were higher than those of ${ }^{232} \mathrm{Th}$. This may because of the radium being more soluble in water (Kitto \& Kim, 2005). ${ }^{40} \mathrm{~K}$ activities ranged from $0.66 \mathrm{~Bq} \cdot \mathrm{L}^{-1}\left(w^{7}\right)$ to $5.64 \mathrm{~Bq} \cdot \mathrm{L}^{-1}\left(w^{4}\right)$, all samples concentration were below the recommended limit $10.0 \mathrm{~Bq} \cdot \mathrm{L}^{-1}$ of ${ }^{40} \mathrm{~K}$ reported by WHO 2006 (WHO, 2006). The obtained average concentrations of the three nuclides $\left({ }^{226} \mathrm{Ra}\right.$, ${ }^{232} \mathrm{Th}$, and ${ }^{40} \mathrm{~K}$ ) were $0.85,0.43$ and $2.84 \mathrm{~Bq} \cdot \mathrm{L}^{-1}$, respectively. The average values 
Table 1. Activity concentrations of ${ }^{226} \mathrm{Ra},{ }^{232} \mathrm{Th}$, and ${ }^{40} \mathrm{~K}$ of the ground water samples.

\begin{tabular}{|c|c|c|c|c|c|}
\hline \multirow{2}{*}{ Samples } & \multicolumn{3}{|c|}{ Concentrations $(\mathrm{Bq} / \mathrm{L})$} & \multirow{2}{*}{$\begin{array}{c}\text { Annual effective } \\
\text { dose (mSv/y) }\end{array}$} & \multirow{2}{*}{$\begin{array}{c}\text { Lifetime risk } \\
(R) \times 10^{-3}\end{array}$} \\
\hline & ${ }^{226} \mathrm{Ra}$ & ${ }^{232} \mathrm{Th}$ & ${ }^{40} \mathrm{~K}$ & & \\
\hline w1 & $0.98 \pm 0.25$ & ND & $1.36 \pm 0.07$ & 0.069 & 0.352 \\
\hline$w 2$ & $0.65 \pm 0.003$ & ND & $1.60 \pm 0.08$ & 0.047 & 0.239 \\
\hline w3 & ND & ND & $2.63 \pm 0.13$ & 0.004 & 0.02 \\
\hline$w 4$ & $0.28 \pm 0.10$ & $0.46 \pm 0.21$ & $5.64 \pm 0.96$ & 0.053 & 0.273 \\
\hline$w 5$ & $1.52 \pm 0.70$ & ND & $4.70 \pm 1.04$ & 0.111 & 0.565 \\
\hline w6 & $3.00 \pm 1.70$ & $0.55 \pm 0.16$ & $1.17 \pm 0.05$ & 0.237 & 1.211 \\
\hline$w 7$ & $1.12 \pm 0.24$ & $0.67 \pm 0.30$ & ND & 0.114 & 0.582 \\
\hline$w 8$ & $0.29 \pm 0.10$ & ND & ND & 0.019 & 0.101 \\
\hline w9 & ND & ND & $2.50 \pm 1.10$ & 0.004 & 0.001 \\
\hline$w 10$ & $1.54 \pm 0.36$ & ND & $3.10 \pm 1.10$ & 0.108 & 0.553 \\
\hline$w 11$ & $0.59 \pm 0.12$ & ND & ND & 0.040 & 0.205 \\
\hline$w 12$ & $0.40 \pm 0.13$ & ND & $4.65 \pm 0.22$ & 0.034 & 0.175 \\
\hline$w 13$ & $1.31 \pm 0.25$ & ND & $3.24 \pm 0.17$ & 0.094 & 0.481 \\
\hline$w 14$ & $0.53 \pm 0.14$ & $0.81 \pm 0.26$ & $0.92 \pm 0.04$ & 0.083 & 0.424 \\
\hline$w 15$ & $0.34 \pm 0.21$ & $0.15 \pm 0.02$ & $3.24 \pm 0.16$ & 0.036 & 0.186 \\
\hline$w 16$ & $0.24 \pm 0.09$ & ND & $0.66 \pm 0.04$ & 0.017 & 0.08 \\
\hline$w 17$ & $0.42 \pm 0.24$ & $0.17 \pm 0.02$ & $4.28 \pm 0.22$ & 0.016 & 0.08 \\
\hline$w 18$ & ND & ND & $3.95 \pm 0.19$ & 0.006 & 0.03 \\
\hline$w 19$ & $0.46 \pm 0.14$ & $0.20 \pm 0.12$ & $1.83 \pm 0.019$ & 0.045 & 0.231 \\
\hline$w 20$ & ND & $0.42 \pm 0.13$ & $5.38 \pm 0.29$ & 0.032 & 0.162 \\
\hline Range & $0.24-1.52$ & $0.15-0.81$ & $0.66-5.64$ & $0.004-0.237$ & $0.001-1.211$ \\
\hline Average & 0.85 & 0.43 & 2.84 & 0.058 & 0.299 \\
\hline WHO 2006 & 1 & 0.1 & 10 & 1.0 & \\
\hline
\end{tabular}

ND: not detected.

for ${ }^{226} \mathrm{Ra}$ and ${ }^{40} \mathrm{~K}$ do not exceed the WHOO 2006 recommended limit in drinking water, whereas, slightly higher for ${ }^{232} \mathrm{Th}$ than the limit. It should be noted that, in the present results, ${ }^{40} \mathrm{~K}$ is the most abundant concentration, about $76 \%$ of the total $\left({ }^{226} \mathrm{Ra}+{ }^{232} \mathrm{Th}+{ }^{40} \mathrm{~K}\right)$. Potassium-40 is an isotope of an essential element which is under homeostatic control (Jabir et al., 2007). The activity concentration of ${ }^{226} \mathrm{Ra},{ }^{232} \mathrm{Th}$ and ${ }^{40} \mathrm{~K}$ in the studied ground water samples illustrated in Figure 2.

\subsection{Radiation Dose Estimation}

The annual effective dose equivalents from the consumption of drinking water due to ${ }^{226} \mathrm{Ra},{ }^{232} \mathrm{Th}$, and ${ }^{40} \mathrm{~K}$ were estimated by UNSCEAR (2000) and El-Gamal et al. (2019) as:

$$
D_{w}=A_{w} \times C_{w} \times F_{w}
$$


where $D_{w}$ is the annual effective dose equivalent from consumption of drinking water (mSv/year), $A_{w}$ is the activity concentration of radionuclides in the ingested water $(\mathrm{Bq} / \mathrm{L}), C_{w}$ is the consumption rate of water (L/year). According to WHO (2003), the dose was estimated by considering a consumption rate is 730 L/year for adults. The dose conversion factors $F_{w}(\mathrm{~Sv} / \mathrm{Bq})$ for adults were $(2.8 \times$ $10^{-7}, 2.3 \times 10^{-7}$ and $\left.6.2 \times 10^{-9} \mathrm{~Sv} \mathrm{~Bq}{ }^{-1}\right)$ for ${ }^{226} \mathrm{Ra},{ }^{232} \mathrm{Th}$ and ${ }^{40} \mathrm{~K}$, respectively, (WHO, 2006).

The calculated total annual effective doses for adults ingested radionuclides ${ }^{226} \mathrm{Ra},{ }^{232} \mathrm{Th}$ and ${ }^{40} \mathrm{~K}$ from the ground water samples were tabulated in Table 1. The highest value $(0.237 \mathrm{mSv} / \mathrm{y})$ of effective dose was calculated in sample w6 due to the radium high concentration. The range of effective doses due to intake of ${ }^{226} \mathrm{Ra}$, ${ }^{232} \mathrm{Th}$, and ${ }^{40} \mathrm{~K}$ were from 0.004 to $0.237 \mathrm{mSv} / \mathrm{y}$, with an average value of $0.058 \mathrm{mSv} / \mathrm{y}$ which is below the average limit $(0.1 \mathrm{mSv} / \mathrm{y})$ reported by WHO (WHO, 2006). Consequently, we recommended that, the investigated waters are acceptable as drinking water for life-long human without any treatment to reduce the concentrations of radioactive contaminants. Figure 3 , shows the effective dose for the ingestion of ${ }^{226} \mathrm{Ra},{ }^{232} \mathrm{Th}$ and ${ }^{40} \mathrm{~K}$ by adults.

\subsection{Lifetime Risk Assessment ( $R$ )}

Lifetime risk assessment was calculated using the Eq (EPA, 1999):

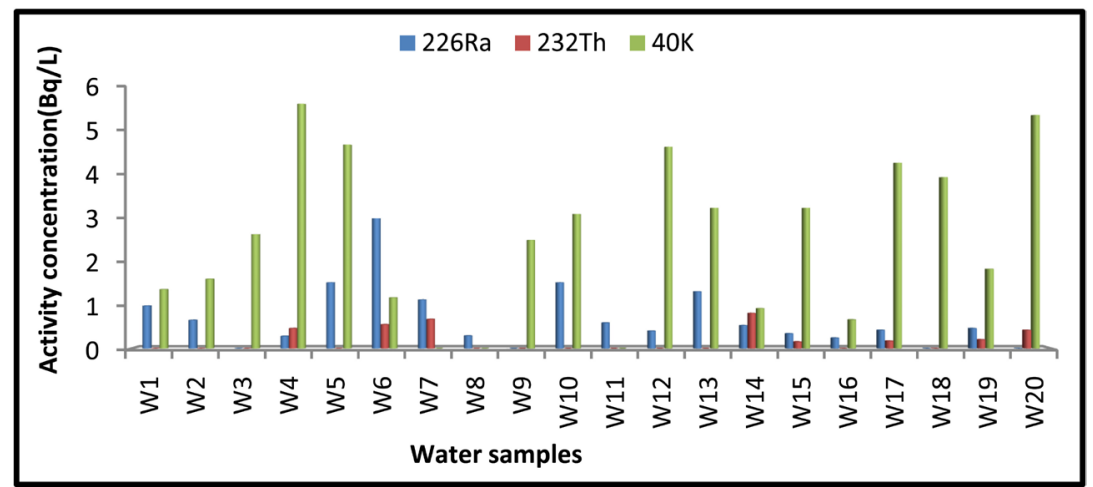

Figure 2. Activity concentration of ${ }^{226} \mathrm{Ra},{ }^{232} \mathrm{Th}$ and ${ }^{40} \mathrm{~K}$ in ground water samples collected from Al-Baha region, Saudi Arabia.

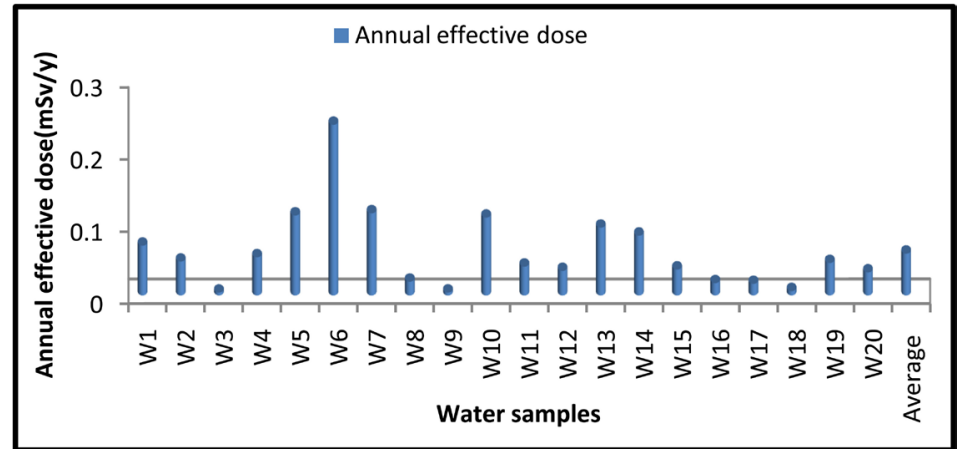

Figure 3. A comparison of total annual effective dose $(\mathrm{mSv} / \mathrm{y})$ for adults ingested radionuclides ${ }^{226} \mathrm{Ra},{ }^{232} \mathrm{Th}$ and ${ }^{40} \mathrm{~K}$ from the ground water samples. 


$$
\text { Lifetime risk }(R)=D_{w} \times D_{L} \times R_{F}
$$

where $D_{W}$ is annual effective dose equivalent (Sv/y), $D_{L}$ is duration of life (70 years) and $R_{F}$ is risk factor $\left(\mathrm{Sv}^{-1}\right)$. For risk assessment, the nominal probability coefficient of $7.3 \times 10^{-2} \mathrm{~Sv}^{-1}$ was adopted (ICRP, 1996).

The risk levels from the direct ingestion of the natural radionuclides in ground water were estimated as shown in Table 1 . The cancer risk $R$ for the adults, i.e. corresponding to the total ingestion dose of $0.058 \mathrm{mSv} / \mathrm{y}$ is estimated as $0.299 \times 10^{-3}$. This risk is much lower than the limit $8.4 \times 10^{-3}$, if the total natural radiation dose of $2.4 \mathrm{mSv} / \mathrm{y}$ as given by UNSCEAR 2000 UNSCEAR (2000).

\subsection{Comparison of Results with Similar in Other Countries}

Table 2 shows a comparison between the measured activity concentration values of the groundwater samples in present work and other samples obtained from different countries. Where, the average concentration of ${ }^{226} \mathrm{Ra}\left(0.56 \mathrm{~Bq} \cdot \mathrm{L}^{-1}\right)$ is acceptable with all countries except the maximum values for Yemen and Nigeria. ${ }^{232} \mathrm{Th}$ average value $\left(0.16 \mathrm{~Bq} \cdot \mathrm{L}^{-1}\right)$ is almost matched with Saudi Arabia (Alseroury et al., 2018), higher than Jordan (Al-Shboul et al., 2017) and lower than other countries. The present results show that the average of ${ }^{40} \mathrm{~K}$ concentration is nearly matching the value of Nigeria (Ajayi \& Owolabi, 2007), higher than Yemen (Abdurabu et al., 2016) and Jordan (Al-Shboul et al., 2017), while it is lower than the other observed values. Therefore, we can indicate that the obtained results are in agreement with the data obtained from various locations in the world, taking into account the data of the countries of different geographical locations differ regarding specific mineral.

\section{Conclusion}

The activities of ${ }^{226} \mathrm{Ra},{ }^{232} \mathrm{Th}$ and ${ }^{40} \mathrm{~K}$ in the well water samples collected from Al-Baha region, south-east of Saudi Arabia were investigated in the present study. The obtained average concentrations of the three nuclides $\left({ }^{226} \mathrm{Ra},{ }^{232} \mathrm{Th}\right.$, and ${ }^{40} \mathrm{~K}$ ) were $0.85,0.43$ and $2.84 \mathrm{~Bq} \cdot \mathrm{L}^{-1}$, respectively. The results indicate that

Table 2. Activity concentration of natural radionuclides in ground water from different countries.

\begin{tabular}{ccccc}
\hline & \multicolumn{2}{c}{ Activity concentrations in $(\mathrm{Bq} / \mathrm{L})$} & & References \\
\cline { 2 - 4 } Country & ${ }^{226} \mathrm{Ra}$ & ${ }^{232} \mathrm{Th}$ & ${ }^{40} \mathrm{~K}$ & \\
\hline Saudi Arabia (Al-Baha) & 0.65 & 0.16 & 2.42 & Present work \\
Saudi Arabia (Jeddah) & 0.56 & 0.21 & 4.58 & (Alseroury et al., 2018) \\
Jordan & 0.131 & 0.049 & 0.194 & (Al-Shboul et al., 2017) \\
Nigeria & 4.54 & 0.50 & 2.94 & (Ajayi \& Owolabi, 2007) \\
Yemen & 3.31 & 0.94 & 0.22 & (Abdurabu et al., 2016) \\
Ghana & 0.38 & 0.54 & 5.05 & (Darko et al., 2015) \\
WHOO & 1 & 0.1 & 10 & (WHO, 2006) \\
\hline
\end{tabular}


the natural radioactivity concentrations of these nuclides were below the WHO guidance levels and were within the values reported by the other researchers. The risk assessment data show that the investigated radionuclides in water were below limit values and pose no detrimental health effect.

\section{Acknowledgements}

A special thanks to Nada Alshehri for helping in proofreading and organizing the paper.

\section{Conflicts of Interest}

The author declares no conflicts of interest regarding the publication of this paper.

\section{References}

Abbady, A. G. (2004). Estimation of Radiation Hazard Indices from Sedimentary Rocks in Upper Egypt. Applied Radiation and Isotopes, 60, 111-114. https://doi.org/10.1016/j.apradiso.2003.09.012

Abdurabu, W. A., Saleh, M. A., Ramli, A. T., \& Heryansyah, A. (2016). Occurrence of Natural Radioactivity and Corresponding Health Risk in Groundwater with an Elevated Radiation Background in Juban District, Yemen. Environmental Earth Sciences, 75, 1360. https://doi.org/10.1007/s12665-016-6142-z

Ajayi, O. S., \& Owolabi, T. P. (2007). Determination of Natural Radioactivity in Drinking Water in Private Dug Wells in Akure, Southwestern Nigeria. Radiation Protection Dosimetry, 128, 477-484. https://doi.org/10.1093/rpd/ncm429

Alseroury, F. A., Almeelbi, T., Khan, A., Barakata, M. A., Al-Zahrani, J. H., \& Alali, W. (2018). Estimation of Natural Radioactive and Heavy Metals Concentration in Underground Water. Journal of Radiation Research and Applied Sciences, 11, 373. https://doi.org/10.1016/j.jrras.2018.07.004

Al-Shboul, K. F., Alali, A. E., Batayneh, I. M., \& Al-Khodire, H. Y. (2017). Radiation Hazards and Lifetime Risk Assessment of Tap Water Using Liquid Scintillation Counting and High-Resolution Gamma Spectrometry. Journal of Environmental Radioactivity, 178-179, 245-252. https://doi.org/10.1016/j.jenvrad.2017.09.005

Darko, G., Faanu, A., Akoto, O., Acheampong, A., Goode, E. J., \& Gyamfi, O. (2015). Distribution of Natural and Artificial Radioactivity in Soils, Water and Tuber Crops. Environmental Monitoring and Assessment, 187, 339. https://doi.org/10.1007/s10661-015-4580-9

Degerlier, M., \& Karahan, G. (2010). Natural Radioactivity in Various Surface Waters in Adana, Turkey. Desalination, 261, 126-130. https://doi.org/10.1016/j.desal.2010.05.020

El-Gamal, H., Sefelnasr, A., \& Salaheldin, G. (2019). Determination of Natural Radionuclides for Water Resources on the West Bank of the Nile River, Assiut Governorate Egypt. Water, 11, 311. https://doi.org/10.3390/w11020311

EPA (1999). Radon in Drinking Water Health Risk Reduction and Cost Analysis. Federal Register, 64, 9560-9599.

IAEA (International Atomic Energy Agency) (1989). Measurement of Radiation in Food and the Environment. Guidebook. Technical Report Series. Vienna: IAEA.

ICRP (1996). European Commission Directive. Laying down Basic Safety Standards for 
the Protection of the Health of Workers and the General Public against the Dangers Arising from Ionizing Radiation. EC Directive.

Jabir, N. N., Farad, I. P., \& Alas, S. K. (2007). Activity Concentrations of ${ }^{226}$ Ra, ${ }^{228} \mathrm{Th}$, and ${ }^{40} \mathrm{~K}$ in Different Food Crops from a High Background Radiation Area in Bitschi, Joss Plateau, Nigeria. Radiation and Environmental Biophysics, 46, 53-59. https://doi.org/10.1007/s00411-006-0085-9

Kitto, M. E., \& Kim, M. S. (2005). Naturally Occurring Radionuclides in Community Water Supplies of New York State. Health Physics, 88, 253-260. https://doi.org/10.1097/01.HP.0000149879.58455.1f

Kraemer, T. F., \& Genereux, D. P. (1998). Applications of Uranium-and Thorium-Series Radionuclides in Catchment Hydrology Studies. In Isotope Tracers in Catchment Hydrology (pp. 679-722). Amsterdam: Elsevier.

https://doi.org/10.1016/B978-0-444-81546-0.50027-6

Malanca, A., Repetti, M., \& De Macedo, H. R. (1998). Gross Alpha- and Beta-Activities in Surface and Ground Water of Rio Grande do Norte, Brazil. Applied Radiation and Isotopes, 49, 893-898. https://doi.org/10.1016/S0969-8043(97)00298-4

Salih, M. M. I., Pettersson, H. B. L., \& Lund, E. (2002). Uranium and Thorium Series Radionuclides in Drinking Water from Drilled Bedrock Wells: Correlation to Geology and Bedrock Radioactivity and Dose Estimation. Radiation Protection Dosimetry, 102, 249-258. https://doi.org/10.1093/oxfordjournals.rpd.a006093

Todorović, N., Nikolov, J., Tenjović, B., Bikit, I., \& Veskovic, M. (2012). Establishment of a Method for Measurement of Gross Alpha/Beta Activities in Water from Vojvodina Region. Radiation Measurements, 47, 1053-1059.

https://doi.org/10.1016/j.radmeas.2012.09.009

UNSCEAR (2000). The United Nations Scientific Committee on the Effects of Atomic Radiation (pp. 93+156). Report to General Assembly. New York: United Nations.

WHO (2003). World Health Organization, Guidelines for Drinking Water Quality (Vol. 3). Geneva, Switzerland: WHO.

WHO (2006). Guidelines for Drinking-Water Quality (Vol. 1, 3rd ed.). Geneva, Switzerland: WHO. 